\title{
The description and evaluation of technical incident risk on the National Power Grid in the context of power safety growth
}

\author{
Daniel N. Fiț̆ă $\breve{1}^{1, *}$, Crina Barb $^{1}$, Dragoș Păsculescu ${ }^{1}$, and Leon Pană ${ }^{1}$ \\ ${ }^{1}$ University of Petrosani, 332093 Petrosani, Romania
}

\begin{abstract}
In the context of increasing the importance of power safety for national security, the security of power systems within the National Power Grid, must be an objective of major and constant interest for the national transmission and system operator. Evolutions in recent decades have shown the increase in vulnerabilities caused by: failure, destruction and/or disruption of technological infrastructures caused by acts of terrorism, natural disaster, negligence in service, work accidents of technical nature, technical incidents, criminal activities and lack of investment. For the critical analysis of the National Power Grid, 4 (four) possible risk scenarios with effects of instability of the power safety and with major effects on the national security were identified, described and evaluated: Risk Scenario 1 - Technical Incident, Risk Scenario 2 - Damage: Technical Incident Sequence, Risk Scenario 3 - Damage: Natural Disaster, Risk Scenario 4 Damage: Terrorist Attack. The purpose of the paper is to describe and evaluate the Risc Scenario 1 - Technical Incident (which is most prevalent) on the power substations and to prevent potential disturbances in the safety of the power supply to consumer.
\end{abstract}

\section{National Power Grid Generalities - NPG}

\subsection{The purpose of NPG}

The purpose of NPG's existence is to ensure all safety, technical and economic requirements of consumers's supplying with electrical or thermal energy.

In order to do that, NPG must meet the following requirements:

- safety (security) in consumers`s supplying;

- $\quad$ the quality of electricity;

- the economicity;

- external requirements.

\footnotetext{
* Corresponding author: daniel.fita@yahoo.com
} 


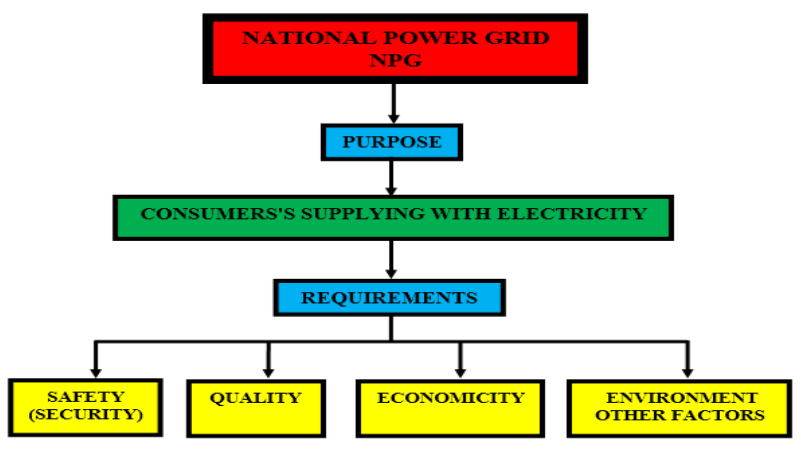

Fig. 1. The purpose and requirements of NPG

\subsection{NPG statuses}

NPG can be functionally found in one of the following status:

- $\quad$ normal operation status - N;

- $\quad$ exposed status (alarm) - E;

- critical status - C;

- damage status - D.

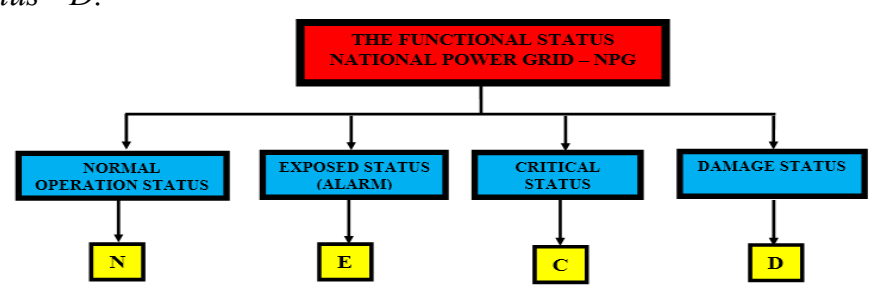

Fig. 2. Functional status of NPG: N - normal operation status; E - exposed status (alarm); C critical status; D - damage status

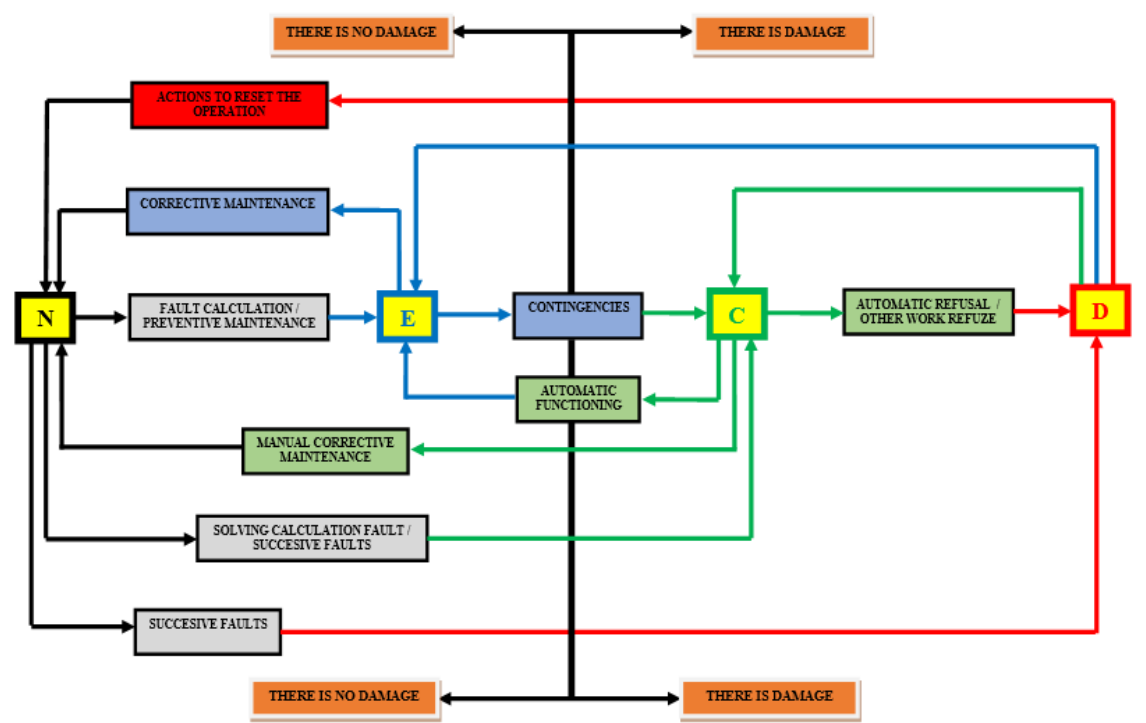

Fig. 3. NPG status and transition from one status to another status: $\mathrm{N}$ - normal operation status; $\mathrm{E}-$ exposed status (alarm); C - critical status; D - damage status 


\subsection{NPG interconnection with neighboring power systems}

NPG interconnection is one of the main ways to increase its reliability and safety, without affecting power independence.

These interconnections provide emergency assistance without the need of installing and maintaining of a strong power reserve.

International interconnections of Romanian NPG:

$>$ Ukraine:

- $\quad$ OHL 400 kV Roșiori - Mukacevo;

- Hungary:

- $\quad$ OHL 400 kV Nădab - Bekescsaba;

- OHL $400 \mathrm{kV}$ Arad - Sandorfalva.

$>$ Serbia:

- OHL 400 kV Reșiţa - Pancevo 2;

- OHL 400 kV Portile de Fier 1 - Djerdap.

- Bulgaria:

- $\quad$ OHL 400 kV Țănțăreni - Koslodui;

- OHL 400 kV Rahman - Dobrudja;

- OHL 400 kV Stupina - Varna.

Republic of Moldova:

- $\quad$ OHL 400 kV Isaccea - Vulcănești.

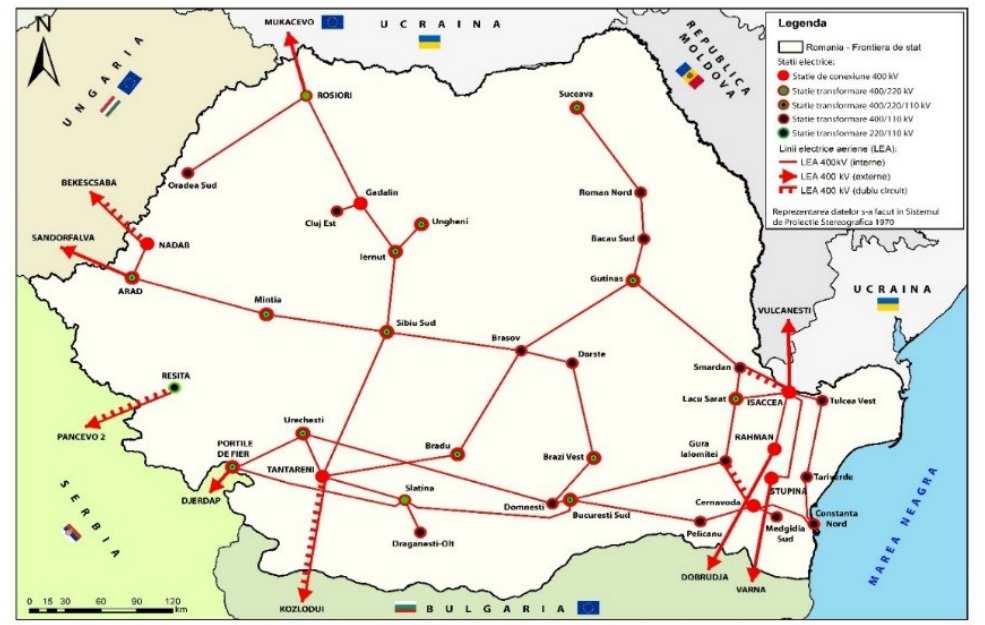

Fig. 4. Transmission Electricity Map at the $400 \mathrm{kV}$ and the interconnection with the neighboring power systems

\subsection{Faults's typology (threats) in NPG operation}

In NPG's, installations and power equipment running (power plants, electrical networks) it may occure different faults (threats) as follows:

\footnotetext{
- current malfunctions,

- faults;

- incidents:

- isolated;

- associated.

- damages.
} 


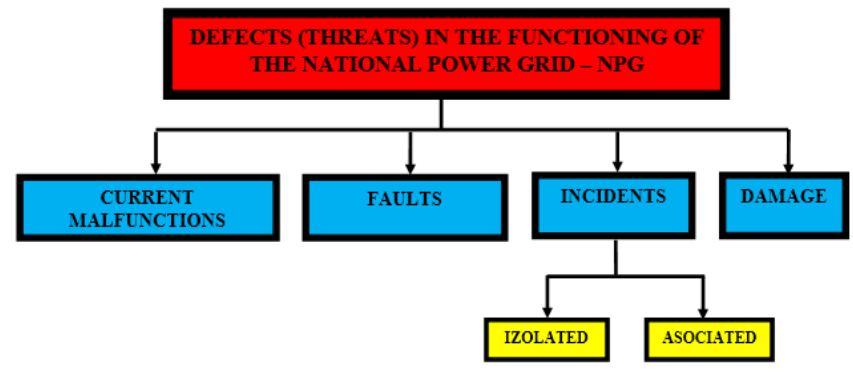

Fig. 5. Faults NPG's running

\subsection{Real functioning of the romanian NPG}

In Romania, the responsability for the safety and security of NPG running lies with the National Power Grid Company TRANSELECTRICA S.A.

NPG is interconnected to ENTSO-E (European Networks of Transmission System Operators for Electricity), which is the european transport system for European Union (Hungary, Bulgaria, North Ukraine) and the energy systems of Serbia, the Republic of Moldova.

Responsibilities of National Power Grid Company TRANSELECTRICA SA:

- electricity transmission operator:

- exploatation of electricity transmission network infrastructure;

- maintenance of electricity transmission network infrastructure;

- development of electricity transmission network infrastructure;

- on: 81 power substations and 8834,5 km. overhead lines;

- through 8 power transmission branches and 5 subsidiaries (Opcom, Smart, Formenerg, Teletrans, Icemenerg).

- system operator:

- leading management of NPG;

- operational management of NPG.

- with: EMS / SCADA Dispatch Infrastructure;

- by: 1 National Dispatcher - ND and 5 territorial dispatchers - TD.

- $\quad$ operator on the electricity market:

- electricity exchanges between Romania and the European Union;

- electricity exchanges between Romania, Serbia, Ukraine and the Republic of Moldova.

\section{Identification, description and evaluation of the risk at NPG}

\subsection{Identification of possible risk scenarios with NPG instability effects}

For the critical analysis of the National Power Grid, 4 (four) possible risk scenarios with effects of instability of the power safety and with major effects on the national security were identified:

- $\quad$ Risk Scenario 1 - Technical Incident (Fig. 6, Fig. 7);

- $\quad$ Risk Scenario 2 - Damage: Technical Incident Sequence;

- $\quad$ Risk Scenario 3 - Damage: Natural Disaster;

- $\quad$ Risk Scenario 4 - Damage: Terrorist Attack. 


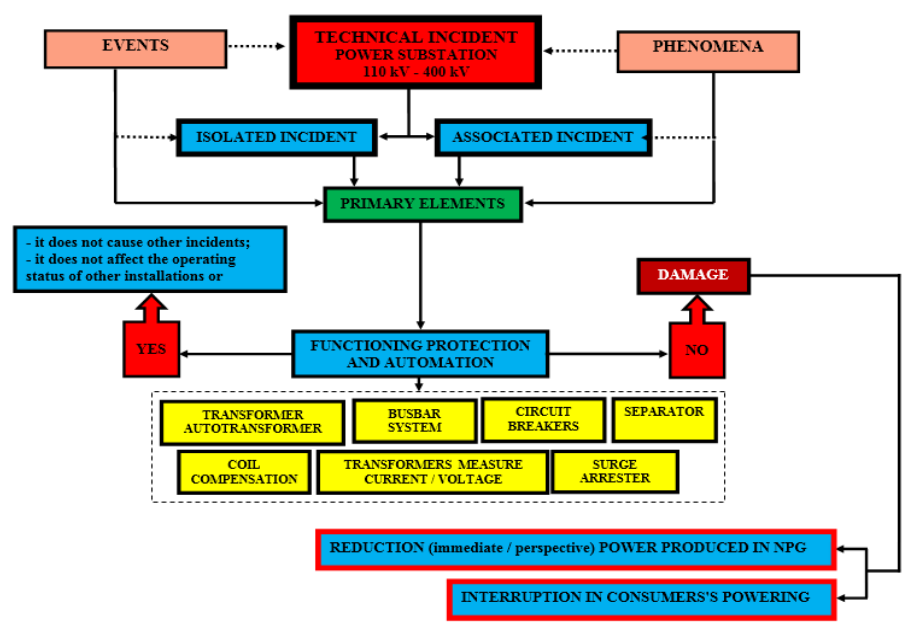

Fig. 6. Timing of phenomena and events in case of a Technical Incident $110 \mathrm{kV}-400 \mathrm{kV}$ power substation

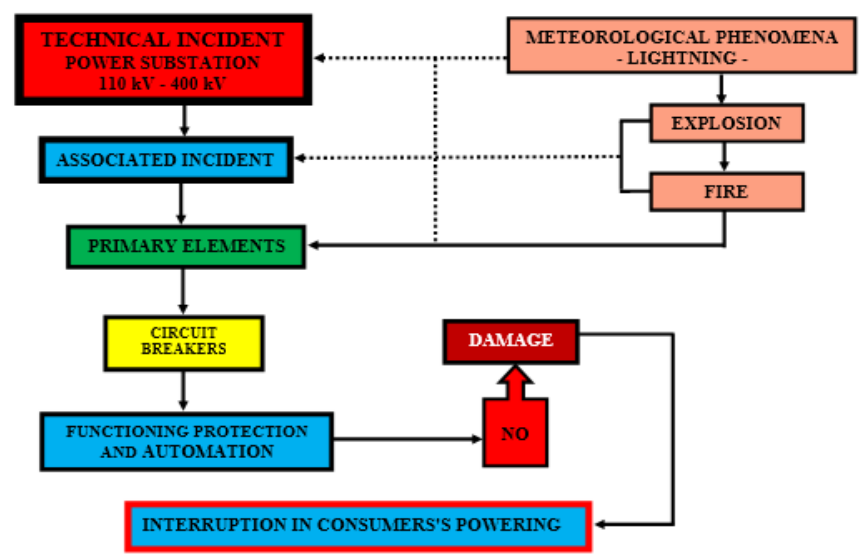

Fig. 7. Risk scenario 1 - Technical Incident: Lightning $\rightarrow$ Explosion $\rightarrow$ Fire $\rightarrow$ Interruption in Consumers's Electricity Supply

\subsection{Risk scenario description 1: TECHNICAL INCIDENT: LIGHTNING $\rightarrow$ EXPLOSION $\rightarrow$ FIRE $\rightarrow$ INTERRUPTION IN CONSUMERS'S ELECTRICITY}

Table 1. Risk Scenario on Power Substations from NPG

\begin{tabular}{|l|l|}
\hline \multicolumn{2}{|c|}{$\begin{array}{l}\text { RISK SCENARIO ON POWER SUBSTATIONS FROM NPG } \\
\text { TECHNICAL INCIDENT: LIGHTNING } \rightarrow \text { EXPLOSION } \rightarrow \text { FIRE } \rightarrow \\
\text { INTERRUPTION IN CONSUMERS'S ELECTRICITY }\end{array}$} \\
\hline GENERAL DESCRIPTION \\
\hline Causes: & $\begin{array}{l}\text { - occurrence of electrical discharges; } \\
\text { - the lack or malfunction of the lightning systems; } \\
\text { - incorrect running of dischargers; } \\
\text { - failure to comply with fire safety regulations; } \\
\text { - failure to comply with occupational safety and health regulations; } \\
\text { - non-use of IPE - individual protective equipment; } \\
\text { - poor condition of power equipment; } \\
\text { - lack of revisions of power equipment; }\end{array}$ \\
\hline
\end{tabular}




\begin{tabular}{|c|c|}
\hline & $\begin{array}{l}\text { - the use of non-compliant power subassemblies; } \\
\text { - lack of investments; } \\
\text { - lack of power substation upgrades; } \\
\text { - lack of specialized and/or trained maintenance personnel; } \\
\text { - lack of specialized and/or trained operative personnel; } \\
\text { - incorrect maneuvers (handling) by power substation personnel; } \\
\text { - failure to communicate or poor communication with TED - Territorial Energy } \\
\text { Dispatcher or DEN - National Energy Dispatcher; } \\
\text { - lack/failure to comply/unawareness of national/european procedures in the event } \\
\text { of serious incident or damage. }\end{array}$ \\
\hline Effects: & $\begin{array}{l}\text { - work accidents from an explosion that may cause fire (unitary or collective) fatal } \\
\text { or incapacitated; } \\
\text { - fire accidents at work (unitary or collective) fatal or incapacitated; } \\
\text { - explosion reach (fire) to other power equipment in the area; } \\
\text { - explosion reach (fire) to other external objectives (forests, houses, blocks, } \\
\text { factories, etc.); } \\
\text { - the disconnection of the equipment in question; } \\
\text { - lack of consumers electric powering; } \\
\text { - material damage resulting from lack of electricity; } \\
\text { - major material damage happened because of other consumers interdependence. }\end{array}$ \\
\hline $\begin{array}{l}\text { Spatial } \\
\text { dimension }\end{array}$ & $\begin{array}{l}\text { - territorial area of electricity transport branches within National Power Grid } \\
\text { Company Transelectrica SA. }\end{array}$ \\
\hline $\begin{array}{l}\text { Temporal } \\
\text { positioning }\end{array}$ & - any time. \\
\hline $\begin{array}{l}\text { Event } \\
\text { duration }\end{array}$ & - between 1 hour and 12 hours, depending on the intervention teams. \\
\hline $\begin{array}{l}\text { Evolution of } \\
\text { the event }\end{array}$ & - the fire can trigger a series of other fires. \\
\hline $\begin{array}{l}\text { Intervention } \\
\text { capacity }\end{array}$ & $\begin{array}{l}\text { - it will intervene in the first phase with its own staff with specific attributions; } \\
\text { - immediately notify ESI - Emergency Situations Inspectorate for fire insulation. }\end{array}$ \\
\hline
\end{tabular}

\subsection{Risk scenario evaluation 1: TECHNICAL INCIDENT: LIGHTNING $\rightarrow$ EXPLOSION $\rightarrow$ FIRE $\rightarrow$ INTERRUPTION IN CONSUMERS'S ELECTRICITY}

\section{a) Establishing the probability}

To establish the probability of occurrence, the following probability scale was adopted (tabel 2):

Table 2. Scenario 1: Tehnical Incident

\begin{tabular}{|c|c|c|c|}
\hline \multicolumn{4}{|c|}{$\begin{array}{l}\text { SCENARIO 1: TECHNICAL INCIDENT: } \\
\text { XPLOSION } \rightarrow \text { FIRE } \rightarrow \text { INTERRUPTION IN CONSUMERS'S } \\
\text { ELECTRICITY }\end{array}$} \\
\hline \multicolumn{2}{|c|}{$\begin{array}{l}\text { LEVEL / } \\
\text { ASSOCIATED } \\
\text { SCORE }\end{array}$} & DEFINITION OF PROBABILITY & PERIODS \\
\hline & 1. Very low & $\begin{array}{l}\text { It has a very low probability of happening. } \\
\text { Normal measures are required to monitor the } \\
\text { evolution of the event. }\end{array}$ & over 13 years \\
\hline & 2. Low & $\begin{array}{l}\text { The event has a low probability of occurrence. } \\
\text { Efforts are required to reduce the probability } \\
\text { and/or mitigate the impact produced. }\end{array}$ & 10 - 12 years \\
\hline & 3. Medium & $\begin{array}{l}\text { The event has a significant probability of } \\
\text { happening. Significant efforts are required to } \\
\text { reduce the probability and/or mitigate the impact. }\end{array}$ & 7 - 9 years \\
\hline $\mathbf{X}$ & 4. High & The event is likely to happen. Priority efforts are & 4 - 6 years \\
\hline
\end{tabular}




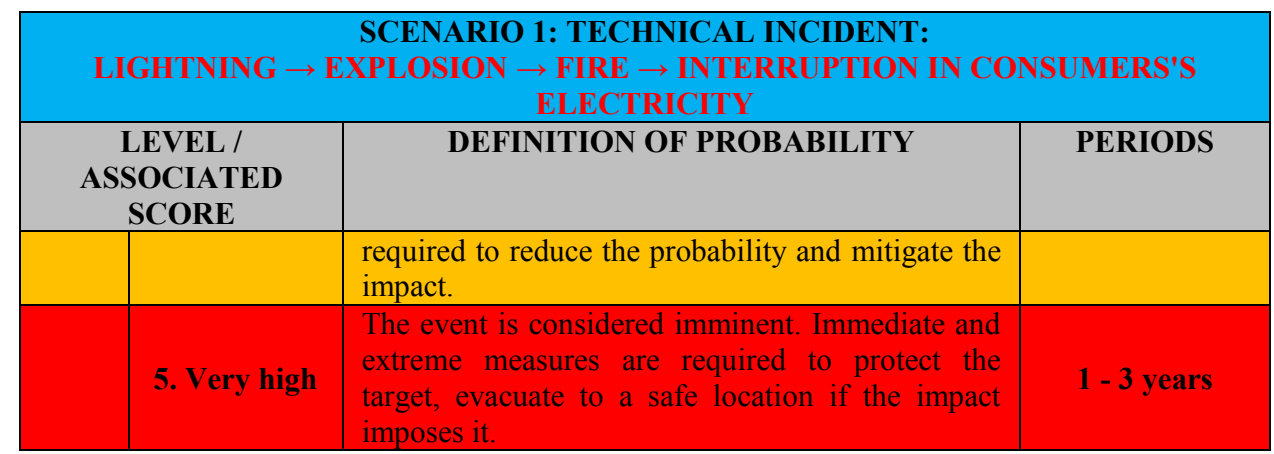

b) Determining the gravity of the consequences of the proposed scenario

The gravity of the consequences is given by the worst level of vulnerabilities and levels of impact.

- Analysis of vulnerabilities and capabilities (tabel 3)

Table 3. Scenario 1: Tehnical Incident - Analysis of vulnarabilities and capabilities

\begin{tabular}{|c|c|}
\hline $\begin{array}{c}\text { SCENARIO 1: TECHNICAL INCIDENT: } \\
\text { LIGHTNING } \rightarrow \text { EXPLOSION } \rightarrow \text { FIRE } \rightarrow \text { INTERRUPTION IN } \\
\text { CONSUMERS'S ELECTRICITY } \\
\text { VULNERABILITIES AND CAPABILITIES }\end{array}$ & LEVEL \\
\hline \multirow{5}{*}{$\begin{array}{l}\text { 1. Location of the power substation (european critical infrastructure) from the } \\
\text { safety point of view in the supply of electricity to consumers: } \\
\text { - zonal, regional and national consumers; } \\
\text { - national interconnection; } \\
\text { - interconnection with neighboring power systems. }\end{array}$} & Very low \\
\hline & Low \\
\hline & Medium \\
\hline & High \\
\hline & Very high \\
\hline \multirow[t]{5}{*}{ 2. Degree of specialization and training of fire intervention personnel } & Very low \\
\hline & Low \\
\hline & Medium \\
\hline & High \\
\hline & Very high \\
\hline \multirow{5}{*}{$\begin{array}{l}\text { 3. Degree of specialization and periodic training of the operational personnel } \\
\text { with attributions to restore the power supply process }\end{array}$} & Very low \\
\hline & Low \\
\hline & Medium \\
\hline & High \\
\hline & Very high \\
\hline \multirow[t]{5}{*}{ 4. Equipping the power substation with fire extinguishing equipment } & Very low \\
\hline & Low \\
\hline & Medium \\
\hline & High \\
\hline & Very high \\
\hline \multirow{5}{*}{$\begin{array}{l}\text { 5. Providing operational personnel with individual means and protective } \\
\text { equipment }\end{array}$} & Very low \\
\hline & Low \\
\hline & Medium \\
\hline & High \\
\hline & Very high \\
\hline \multirow{5}{*}{$\begin{array}{l}\text { 6. Existence of safety work procedures for the power substation: } \\
\text { - risk management; } \\
\text { - crisis management; } \\
\text { - emergency management; } \\
\text { - health and safety work management. }\end{array}$} & Very low \\
\hline & Low \\
\hline & Medium \\
\hline & High \\
\hline & Very high \\
\hline \multirow{3}{*}{$\begin{array}{l}\text { 7. Status of the equipment and technological installations related to the } \\
\text { electricity transmission process (lack of investments): } \\
\text { - atmospheric overvoltage protection equipment (lightning strikes, landing gear); }\end{array}$} & Very low \\
\hline & Low \\
\hline & Medium \\
\hline
\end{tabular}




\begin{tabular}{|c|c|}
\hline SCENARIO 1: TECHNICAL INCIDENT: & \\
CIGHTNING $\rightarrow$ EXPLOSION $\rightarrow$ FIRE $\rightarrow$ INTERRUPTION IN & LEVEL \\
VULNERABILITIES AND CAPABILITIES & High \\
\hline - transformer equipment (transformers, autotransformers); & Very high \\
\hline - switching and protection equipment (circuit breakers, separators); & \\
\hline - insulators, measuring transformers (voltage and current), etc. & Very low \\
\hline 8. Technical and human resilience: & Low \\
\hline - the partial or total technical possibility of returning to the initial state; & Medium \\
\hline - the partial or total human chance of returning to the original state. & High \\
\cline { 2 - 2 } & Very high \\
\hline
\end{tabular}

- Impact analysis (tabel 3)

Impact analysis is a management analysis at certain levels that identifies the impact of the loss of resources of a european critical infrastructure (national power substation).

The severity of all scenario impacts will be considered and then the level of severity of the hazard / threat consequences of the scenario considered.

The highest level of severity will be chosen.

Table 4. Impacts

\begin{tabular}{|c|c|c|}
\hline IMPACTS & LEVEL & \\
\hline \multirow[t]{5}{*}{ Potential deaths } & 1. Very low & $0-5$ \\
\hline & 2. Low & $6-10$ \\
\hline & 3. Medium & $11-15$ \\
\hline & 4. High & $16-20$ \\
\hline & 5. Very high & $>21$ \\
\hline \multirow[t]{5}{*}{ Potential injured persons } & 1. Very low & $0-20$ \\
\hline & 2. Low & $21-40$ \\
\hline & 3. Medium & $41-60$ \\
\hline & 4. High & $61-80$ \\
\hline & 5. Very high & $>81$ \\
\hline \multirow{5}{*}{$\begin{array}{c}\text { Potential damage or damage to on-site facilities providing } \\
\text { the main utilities (electricity, communications) }\end{array}$} & 1. Very low & temporary \\
\hline & 2. Low & $\begin{array}{l}\text { significant } \\
\text { damage }\end{array}$ \\
\hline & 3. Medium & $\begin{array}{l}\text { average } \\
\text { damage }\end{array}$ \\
\hline & 4. High & great damage \\
\hline & 5. Very high & $\begin{array}{l}\text { very high } \\
\text { damage }\end{array}$ \\
\hline \multirow{5}{*}{$\begin{array}{l}\text { Potential loss or damage to material assets of those to } \\
\text { whom services are provided by the relevant national } \\
\text { critical infrastructure (public, commercial, private) }\end{array}$} & 1. Very low & $0-10 \%$ of $\mathrm{VCI}$ \\
\hline & 2. Low & $\begin{array}{c}11-20 \% \text { of } \\
\text { VCI }\end{array}$ \\
\hline & 3. Medium & $\begin{array}{c}21-30 \% \text { of } \\
\text { VCI }\end{array}$ \\
\hline & 4. High & $\begin{array}{l}31-40 \% \text { of } \\
\text { VCI }\end{array}$ \\
\hline & 5. Very high & $\begin{array}{l}\text { over } 41 \% \text { of } \\
\text { VCI }\end{array}$ \\
\hline \multirow[t]{5}{*}{ Potential loss or damage to the environment } & 1. Very low & $0-20 \%$ \\
\hline & 2. Low & $21-40 \%$ \\
\hline & 3. Medium & $41-60 \%$ \\
\hline & 4. High & $61-80 \%$ \\
\hline & 5. Very high & over $81 \%$ \\
\hline Potential social impacts & 1. Very low & $0-10 \%$ of PT \\
\hline
\end{tabular}




\begin{tabular}{|l|c|c|}
\hline IMPACTS & LEVEL & \\
\hline \multirow{5}{*}{} & 2. Low & $11-20 \%$ of PT \\
\cline { 2 - 3 } & $\mathbf{3 .}$ Medium & $21-30 \%$ of PT \\
\cline { 2 - 3 } & 4. High & $31-40 \%$ of PT \\
\cline { 2 - 3 } & 5. Very high & over $41 \%$ of PT \\
\hline VCI-Value Chain Insight; PT - People Trust \\
\hline
\end{tabular}

Table 5. Gravity of the consequences

\begin{tabular}{|c|c|l|}
\hline \multicolumn{2}{|c|}{$\begin{array}{c}\text { LEVEL / } \\
\text { ASSOCIATED } \\
\text { SCORES }\end{array}$} & \multicolumn{1}{c|}{ GRAVITY OF THE CONSEQUENCES } \\
\hline 1. Very low & $\begin{array}{l}\text { The event produces a minor disturbance in the working process without } \\
\text { material damage }\end{array}$ \\
\hline & 2. Low & $\begin{array}{l}\text { The event produces minor material losses and limited activity } \\
\text { disturbance }\end{array}$ \\
\hline X & 3. Medium & $\begin{array}{l}\text { Personal injury, and/or some loss of equipment, utilities, and delays in } \\
\text { service providing. }\end{array}$ \\
\hline & 5. Very high & $\begin{array}{l}\text { Serious injury to personnel, significant losses of instalation equipment, } \\
\text { delays and/or disruption of service provision. }\end{array}$ \\
\hline $\begin{array}{l}\text { Consequences are catastrophic resulting in deaths and serious personal } \\
\text { injury, major loss of equipment, instalations and facilities, and the } \\
\text { cessation of service provision. }\end{array}$ \\
\hline
\end{tabular}

c) Calculation of risk level (Table 6)

In table 6 are presented the probability and gravity of the consequences and the calculated risk level.

Table 6. Probability / Gravity of the consequences

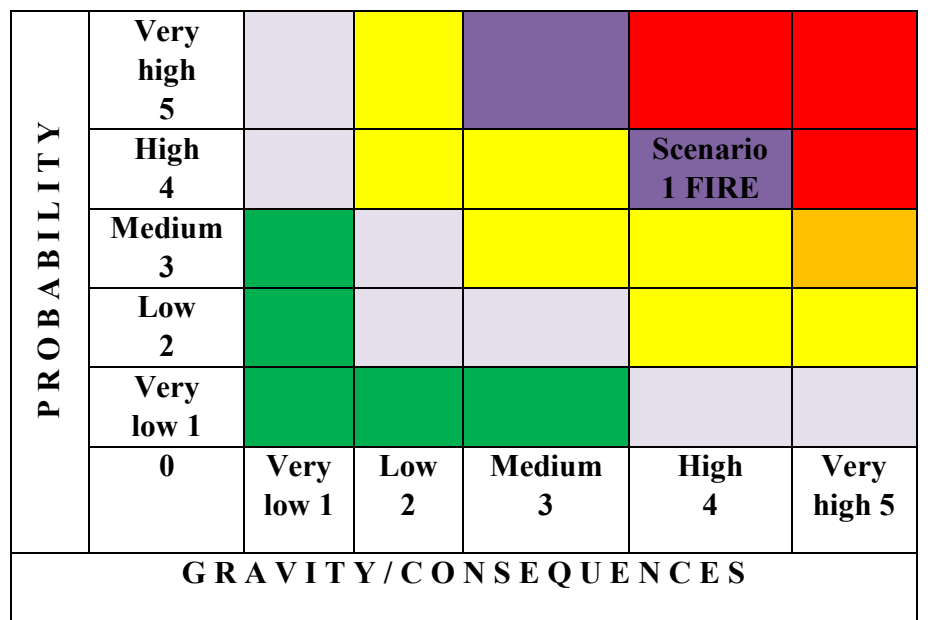

\begin{tabular}{|c|c|}
\hline \multicolumn{2}{|c|}{ RISC LEVEL } \\
CALCULATED \\
\hline LEVEL & SCORES \\
\hline $\begin{array}{c}\text { Very } \\
\text { low }\end{array}$ & $1-3$ \\
\hline Low & $4-6$ \\
\hline MediuM & $7-12$ \\
\hline High & $13-16$ \\
\hline $\begin{array}{c}\text { Very } \\
\text { high }\end{array}$ & $17-25$ \\
\hline
\end{tabular}

The risk is determined by multiplying the probability of producing a hazard with threats and the severity of its consequences.

The calculated risk is 16 (probability $4 \times$ gravity 4 ) therefore there is a high risk of producing the chosen scenario.

d) Risk treatement (table 7)

To reduce the risk, the next steps are required to cover the following vulnerabilities and/or improve the following capabilities: 
Table 7. Risk treatement

\begin{tabular}{|l|l|}
\hline \multicolumn{1}{|c|}{ VULNERABILITY AND/OR CAPABILITY } & \multicolumn{1}{|c|}{ PROPOSED MEASURES } \\
\hline $\begin{array}{l}\text { Degree of specialization and training of fire } \\
\text { intervention personnel }\end{array}$ & $\begin{array}{l}\text { - training and retraining courses for } \\
\text { emergency situations; } \\
\text { - simulations of interventions (very short } \\
\text { time) in case of fires. }\end{array}$ \\
\hline $\begin{array}{l}\text { Degree of specialization and periodic training of the } \\
\text { operative personnel with attributions to restore the } \\
\text { power supply process }\end{array}$ & $\begin{array}{l}\text { - combined training and retraining courses; } \\
\text { - events and incidents analysis, etc.; } \\
- \text { installations's checking on the operating } \\
\text { line and performing preventive } \\
\text { maintenance. }\end{array}$ \\
\hline $\begin{array}{l}\text { Equipping the power station with fire extinguishing } \\
\text { equipment }\end{array}$ & $\begin{array}{l}\text { - Equipping with individual means of fire } \\
\text { extinguishing }\end{array}$ \\
\hline $\begin{array}{l}\text { Equipment and technological installations related to } \\
\text { the electricity transmission process status (lack of } \\
\text { investments) }\end{array}$ & $\begin{array}{l}\text { major investments in high performance } \\
\text { equipment }\end{array}$ \\
\hline
\end{tabular}

After applying the risk reducing measures we have the next results (table 8):

Table 8. Risk reducing measures

\begin{tabular}{|c|c|c|}
\hline $\begin{array}{l}\text { SCENARIO 1: TECHNICAL INCIDENT: } \\
\text { LIGHTNING } \rightarrow \text { EXPLOSION } \rightarrow \text { FIRE } \rightarrow \\
\text { INTERRUPTION IN CONSUMERS'S } \\
\text { ELECTRICITY } \\
\text { VULNERABILITY } \\
\end{array}$ & IDENTIFIED & $\begin{array}{c}\text { AFTER THE } \\
\text { MEASURES } \\
\text { APPLICATION }\end{array}$ \\
\hline \multirow{5}{*}{ 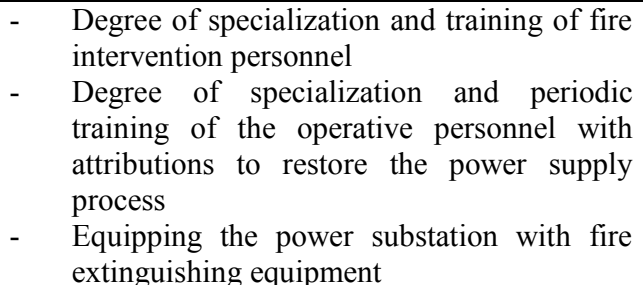 } & 1. Very low & 1. Very low \\
\hline & 2. Low & 2. Low \\
\hline & 3. Medium & 3. Medium \\
\hline & 4. High & 4. High \\
\hline & 5. Very high & 5. Very high \\
\hline
\end{tabular}

e) Recalculating the consequences gravities (table 9)

Table 9. Recalculating the gravity of the consequences

\begin{tabular}{|c|c|l|}
\hline \multicolumn{2}{|c|}{$\begin{array}{c}\text { LEVEL / } \\
\text { ASSOCIATED } \\
\text { SCORES }\end{array}$} & \multicolumn{1}{c|}{ GRAVITY OF CONSEQUENCES } \\
\hline & 1. Very low & $\begin{array}{l}\text { The event produces a minor disturbance in the development of activity } \\
\text { without material damage. }\end{array}$ \\
\hline $\mathbf{X}$ & 2. Low & $\begin{array}{l}\text { The event produces minor material damage and limited activity } \\
\text { disturbance }\end{array}$ \\
\hline & 4. Hedium & $\begin{array}{l}\text { Personal injury, and / or some loss of equipment, utilities, and delays in } \\
\text { providing the service. }\end{array}$ \\
\hline & $\begin{array}{l}\text { Serious injury to personnel, significant loss of instalations and facilities } \\
\text { equipment, delays and / or disruption of service provision. }\end{array}$ \\
\hline 5. Very high & $\begin{array}{l}\text { Consequences are catastrophic resulting in deaths and serious injuries to } \\
\text { staff, major loss of equipment, instalations and facilities, and cessation of } \\
\text { service provision }\end{array}$ \\
\hline
\end{tabular}

\section{f) Risk level after reduction measures applying (table 10)}

The risk is given by the product between the probability of producing a hazard and threats and the severity of its consequences. The calculated risk is 12 (probability $4 \mathrm{x}$ gravity 3 ) therefore there is a medium risk of producing the chosen scenario. 
Table 10. Probability / Gravity of the consequences

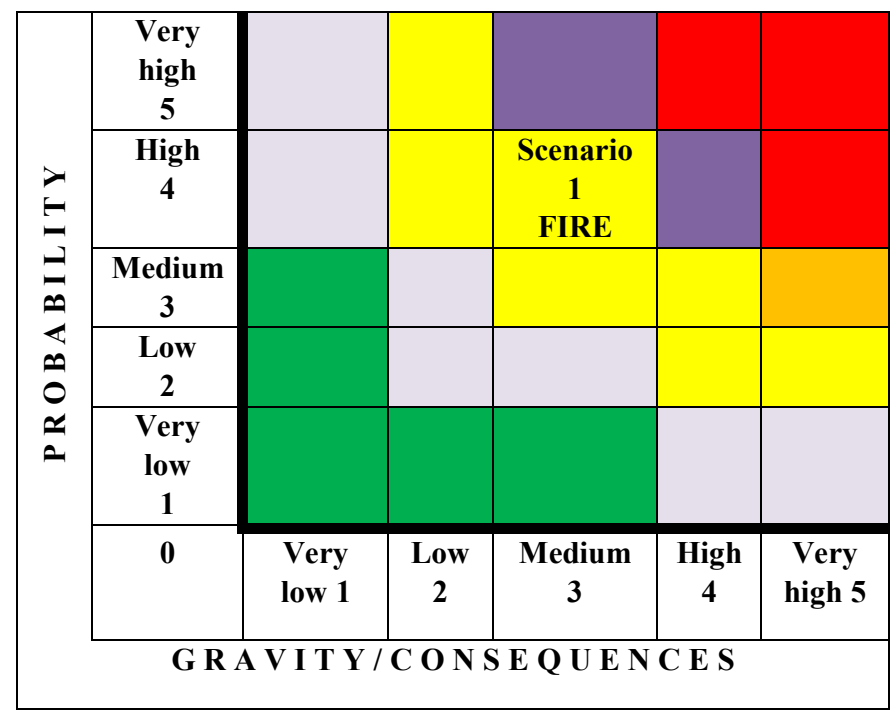

\begin{tabular}{|c|c|}
\hline \multicolumn{2}{|c|}{ RISK LEVEL } \\
CALCULATED \\
\hline LEVEL & SCORES \\
\hline $\begin{array}{c}\text { Very } \\
\text { low }\end{array}$ & $1-3$ \\
\hline Low & $4-6$ \\
\hline Medium & $7-12$ \\
\hline High & $13-16$ \\
\hline $\begin{array}{c}\text { Very } \\
\text { high }\end{array}$ & $17-25$ \\
\hline
\end{tabular}

\section{Conclusion}

After the completion of evaluation SCENARIO 1 - TECHNICAL INCIDENT: LIGHTNING $\rightarrow$ EXPLOSION $\rightarrow$ FIRE $\rightarrow$ INTERRUPTION IN CONSUMERS'S ELECTRICITY, the following facts were determined (table 11):

- to establish the probability of the event to happen, it was selected the scale 4 probability (high);

- level 4 (high) was selected for the severity of the consequences;

- the calculated risk is 16 (high risk);

- after the risk reduction measures have been applied, the severity of the consequences has been recalculated and level 3 (medium) has been selected;

- the recalculated risk is 12 (medium risk).

Table 11. Risk scenario 1

\begin{tabular}{|c|c|c|c|}
\hline \multicolumn{5}{|c|}{ RISK SCENARIO 1 } \\
TECHNICAL INCIDENT: LIGHTNING $\rightarrow$ EXPLOSION $\rightarrow$ FIRE $\rightarrow$ INTERRUPTION \\
IN CONSUMERS'S ELECTRICITY
\end{tabular}

To reduce the risks, the following measures were selected in order to diminish the vulnerabilities and to improve the next capabilities (table 12):

Table 12. Proposed measures

\begin{tabular}{|l|l|}
\hline VULNERABILITY AND/OR CAPABILITY & \multicolumn{1}{c|}{ PROPOSED MEASURES } \\
\hline $\begin{array}{l}\text { Degree of specialization and training of fire } \\
\text { intervention personnel. }\end{array}$ & $\begin{array}{l}\text { - emergency training and retraining courses; } \\
\text { - simulation of interventions (very short time) in } \\
\text { case of fires. }\end{array}$ \\
\hline
\end{tabular}




\begin{tabular}{|l|l|}
\hline VULNERABILITY AND/OR CAPABILITY & \multicolumn{1}{|c|}{ PROPOSED MEASURES } \\
\hline $\begin{array}{l}\text { Degree of specialization and periodic training of } \\
\text { the operational staff with attributions to restore } \\
\text { the power supply process. }\end{array}$ & $\begin{array}{l}\text { - combined training and retraining courses; } \\
\text { - events and incidents analysis etc .; } \\
\text { - installations's checking on the operating line } \\
\text { and performing preventive maintenance }\end{array}$ \\
\hline $\begin{array}{l}\text { Equipping the power station with fire } \\
\text { extinguishing equipment }\end{array}$ & $\begin{array}{l}- \text { equipping with individual means of fire } \\
\text { extinguishing. }\end{array}$ \\
\hline $\begin{array}{l}\text { Equipment and technological installations related } \\
\text { to the electricity transmission process status(lack } \\
\text { of investments). }\end{array}$ & $\begin{array}{l}- \text { major investments in high performance } \\
\text { equipment. }\end{array}$ \\
\hline
\end{tabular}

\section{References}

1. N.D. Fîță, Identifying of vulnerabilities/risk factors of the critical infrastructure in the power installations of ultra high and high voltage from the national power system with international connections, Quality - Access to Success Journal,18 (SI), 103-108 (2017)

2. I. Felea, Reliability Engineering in Power Engineering, Didactic and Pedagogical Publishing House, (2003)

3. I. Mihet, H. Furtunescu, Safety in operation of power equipment-malfunctions, disturbances, incidents and damages, Technical Publishing House, Bucuresti (1987)

4. National Power Grid Company Transelectrica SA, www.transelectrica.ro (2019)

5. L.I. Cioca, R.I. Moraru, G.B. Băbuț, A Framework for Organisational Characteristic Assessment and their Influences on Safety and Health at Work Proceedings of the $15^{\text {th }}$ International Scientific Conference ,The Knowledge Based Organization”, 2, section: Management, 43-48, Land Forces Academy Sibiu, Romania (2009)

6. R.I. Moraru, G.B. Băbuţ, L.I. Cioca, Knowledge management applications in occupational risk assessment processes Proceedings of the $17^{\text {th }}$ International Conference - The Knowledge-Based Organization: Management and Military Sciences, 735-740, Sibiu, Romania (2011)

7. R.I. Moraru, G.B. Băbuţ, Principles and guidelines regarding the risk management implementation: The new ISO 31000:2009 standard, Quality - Access to Success Journal, 11, Issue 4, 50-59 (2010)

8. R.I. Moraru, G.B Băbuț, L.I. Cioca, Drawbacks and traps in risk assessment: examples in Romania Proceedings of the 5th International Conference on Manufacturing Science and Educations - MSE 2011, 2, 363-366, Sibiu, Romania (2011)

9. D.-C. Darabont, C. Bejinariu, C. Baciu, M.-A. Bernevig-Sava, Modern approaches in integrated management systems of quality, environmental and occupational health and safety (Quality Acces to Succes 20, 105-108 (2017)

10. D., Pasculescu, P. Leon, V. Pasculescu, D. Florentiu Economic criteria for optimizing the number and load factor of mining transformer, Mining of Mineral Deposits, 13, Issue1, ISSN 2415-3443 (Online), ISSN 2415-3435 (2019)

11. D. Pasculescu, A., Romanescu, V., Păsculescu, A., Tătar, I., Fotău, G., Vajai Presentation and simulation of a modern distance protection from national energy system, Proceedings of the 10 th International Conference on Environment and Electrical Engineering - EEEIC 2011, Rome, Italy, 646-650, ISBN 978-1-4244-8779-0 (2011)

12. D. Remus, G, Buica, D. Pasculescu, M. Leba Safety Management Diagnostic Method Regarding Work Cost Accidents from Electrical Power Installations Recent advances in industrial and manufacturing technologies, Proceedings of the 1st International Conference on Industrial and Manufacturing Technologies (INMAT '13), Vouliagmeni, Athens, Greece, ISSN: 2227-4596, ISBN: 978-1-61804-186-9, 58-63 (2013) 